\title{
Michael hydratase alcohol dehydrogenase or just alcohol dehydrogenase?
}

\author{
Verena Resch*, Jianfeng Jin, Bi-Shuang Chen and Ulf Hanefeld
}

\begin{abstract}
The Michael hydratase - alcohol dehydrogenase (MhyADH) from Alicycliphilus denitrificans was previously identified as a bi-functional enzyme performing a hydration of a, $\beta$-unsaturated ketones and subsequent oxidation of the formed alcohols. The investigations of the bi-functionality were based on a spectrophotometric assay and an activity staining in a native gel of the dehydrogenase. New insights in the recently discovered organocatalytic Michael addition of water led to the conclusion that the previously performed experiments to identify MhyADH as a bi-functional enzyme and their results need to be reconsidered and the reliability of the methodology used needs to be critically evaluated.
\end{abstract}

Keywords: Michael addition; $\alpha, \beta$-Unsaturated carbonyl compounds; Hydratase; Alcohol dehydrogenase

\section{Introduction}

The Michael addition of water to $\alpha, \beta$-unsaturated ketones is a very interesting but rarely investigated reaction in organic synthesis and only a few procedures are described (Riedel and Krekeler 1972; Mahajan et al. 2006; Wang et al. 2006; Boersma et al. 2010a; Boersma et al. 2010b). In contrast to the low number of chemical methods, nature is capable of performing this reaction and many examples have been described (Jin and Hanefeld 2011). The beauty of this reaction is obvious: Using water as a nucleophile and solvent would allow a green route to hydroxy ketones. Hydratases as biocatalysts would allow an even more environmentally benign approach. Prominent and well studies examples are fumarase, malease, citraconase and enoyl-CoA hydratase. One drawback of the enzymes described is their narrow substrate scope caused by their involvement in (primary) metabolic pathways where specificity is highly important. For their optimal use in biocatalysis, this ability is not desired and therefore new hydratases with a broader substrate spectrum are required. An remarkable example is the use of whole cells from Rhodococcus rhodochrous to catalyse the addition of water to 3-methylor 3-ethyl-2-butenolide reported by Holland and $\mathrm{Gu}$ (1998). Even though no extensive study on the substrate acceptance is reported and the hydratase involved in this

\footnotetext{
* Correspondence: v.a.resch@tudelft.nl

Biocatalysis, Department of Biotechnology, Delft University of Technology, Julianalaan 136, 2628 BL, Delft, The Netherlands
}

transformation is not further characterised, the results are still promising for future investigations on hydratases with a broader substrate scope.

One interesting source of potential hydratases are for example bacteria present in waste water treatment facilities. Waste water is often polluted with man-made chemicals and bacteria can adopt to this situation and acquire the ability to degrade and detoxify their environment. Already in 1988 and 1989 Georg Fuchs and co-workers reported investigations on a denitrifying bacterium from the Pseudomonas genus that is capable of degrading cyclohexanol (Dangel et al. 1988, 1989). In more recent studies they continued their investigations on denitrifying bacteria and results on the organism Alicycliphilus denitrificans (Oosterkamp et al. 2011, 2013; Weelink et al. 2008) are reported (Mechichi et al. 2003). The proposed degradation pathway for cyclic compounds starting from cyclohexanol and the enzymes involved are shown in Figure 1.

This degradation pathway also includes a potential hydratase (2-cyclohexenone hydratase) that is thought to perform the addition of water to 2-cyclohexenone followed by oxidation catalysed by a dehydrogenase to form 1,3cyclohexanedione. To identify and characterise the enzymes involved in the pathway, a native PAGE gel staining was carried out (Dangel et al. 1989).

Later experiments to find and investigate the hydratase described in this pathway were conducted by us, using Alicycliphilus denitrificans DSMZ 14773 as the bacterial

\section{穴}




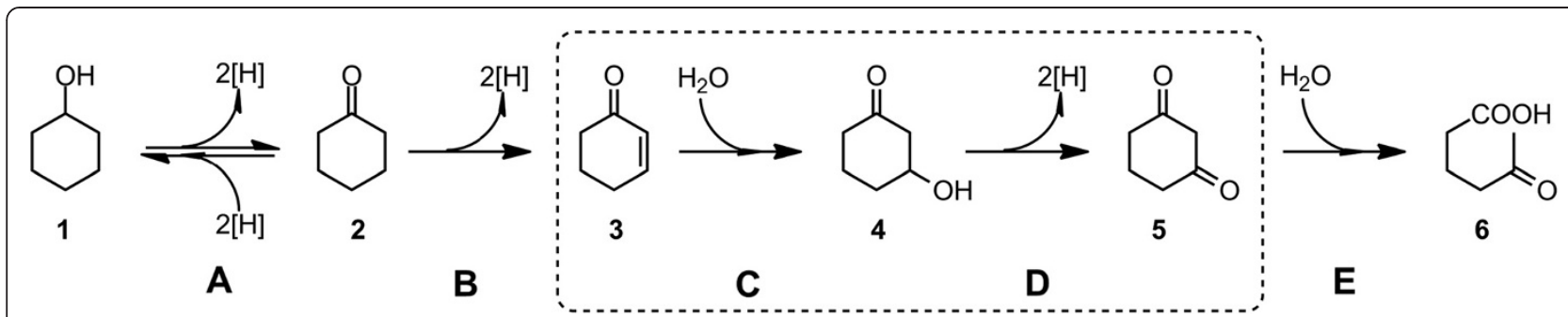

Figure 1 Anaerobic degradation of cyclohexanol by $\boldsymbol{A}$. denitrificans DSMZ 14773. Compounds: 1 cyclohexanol, 2 cyclohexanone, 3 2cyclohexenone, 4 3-hydroxycyclohexanone, 5 1,3-cyclohexanedione, $\mathbf{6}$ 5-oxohexanoic acid. Enzymes: A cyclohexanol dehydrogenase; B cyclohexanone dehydrogenase; C 2-cyclohexenone hydratase; D 3-hydroxycyclohexanone dehydrogenase, E 1,3-cyclohexanedione hydrolase. The figure is based on the pathway proposed by Dangel et al. (1989).

source (Jin et al. 2010; Jin et al. 2011). The search for the hydratase was based on a spectrophotometric assay and the native PAGE gel staining method described by Dangel et al. in 1989. Results from these studies led to the conclusion that the hydratase is a bi-functional enzyme that also possesses the dehydrogenase activity if an electron acceptor is present. Therefore the identified enzyme was called Michael hydratase - alcohol dehydrogenase (MhyADH).

During the investigation on the Michael addition of water to 2-cyclohexenone a background reaction catalysed by proteinogenic amino acids was identified. This reaction was investigated further in recent studies (Resch et al. 2013) that showed, that the reaction is in general base catalysed and that primary amines are good catalysts.

These new findings need to be incorporated into the search for MhyADH and their results indicate that the assumption that MhyADH is a bi-functional enzyme need to be reconsidered. Positive results gained from the spectrophotometric assay and the native PAGE staining might have led to false conclusions. Here we would like to report the new interpretation of the results and comment on the reliability of the assays used.

\section{Materials and methods \\ Chemicals}

Methylene blue, 2,6-dichlorophenol indophenol (DCPIP), and nitro blue tetrazolium chloride (NBT) were purchased from AcrosOrganics and 2-cyclohexenone and xanthine from Sigma Aldrich. $\mathrm{KH}_{2} \mathrm{PO}_{4}$ and $\mathrm{MgSO}_{4} \cdot 7 \mathrm{H}_{2} \mathrm{O}$ were obtained from J. T. Baker. $\mathrm{K}_{2} \mathrm{HPO}_{4}, \mathrm{NH}_{4} \mathrm{Cl}, \mathrm{KNO}_{3}$ and $\mathrm{CaCl}_{2} \cdot 2 \mathrm{H}_{2} \mathrm{O}$ were purchased from Merck. Peptone, meat extract and agar were bought from $\mathrm{BD}$.

\section{Microorganism and culture conditions}

A. denitrificans DSMZ 14773 was purchased from the Deutsche Sammlung von Mikroorganismen und Zellkulturen (DSMZ, Germany). The reactivation medium contained: peptone $(5.0 \mathrm{~g} / \mathrm{L})$, meat extract $(3.0 \mathrm{~g} / \mathrm{L})$, agar (for solid medium, $15.0 \mathrm{~g} / \mathrm{L})$, distilled water $(1000 \mathrm{~mL})$.
Preculture in reactivation medium was grown aerobically at $30^{\circ} \mathrm{C}$ with reciprocal shaking at $150 \mathrm{rpm}$.

Medium for anaerobic cultivation contained: Solution A: $\mathrm{KH}_{2} \mathrm{PO}_{4}(0.816 \mathrm{~g} / 500 \mathrm{~mL}), \mathrm{K}_{2} \mathrm{HPO}_{4}(5.920 \mathrm{~g} / 500 \mathrm{~mL})$, distilled water $(500 \mathrm{~mL})$. Solution B: $\mathrm{NH}_{4} \mathrm{Cl}(0.530 \mathrm{~g} /$ $500 \mathrm{~mL}), \mathrm{MgSO}_{4} \cdot 7 \mathrm{H}_{2} \mathrm{O}(0.200 \mathrm{~g} / 500 \mathrm{~mL}), \mathrm{KNO}_{3}$ $(2.000 \mathrm{~g} / 500 \mathrm{~mL}), \mathrm{CaCl}_{2} \cdot 2 \mathrm{H}_{2} \mathrm{O}(0.025 \mathrm{~g} / 500 \mathrm{~mL})$, distilled water $(500 \mathrm{~mL})$. Solution $\mathrm{A}$ and $\mathrm{B}$ were autoclaved separately, mixed, and $10 \mathrm{~mL}$ of trace element solution SL-10 containing $\mathrm{HCl}(25 \%, 7.7 \mathrm{M}, 10.00 \mathrm{~mL})$, $\mathrm{FeCl}_{2} \bullet 4 \mathrm{H}_{2} \mathrm{O}(1.5 \mathrm{~g} / \mathrm{L}), \mathrm{ZnCl}_{2}(70 \mathrm{mg} / \mathrm{L}), \mathrm{MnCl}_{2} \cdot 4 \mathrm{H}_{2} \mathrm{O}$ $(100 \mathrm{mg} / \mathrm{L}), \mathrm{B}(\mathrm{OH})_{3}(6.00 \mathrm{mg} / \mathrm{L}), \mathrm{CoCl}_{2} \bullet 6 \mathrm{H}_{2} \mathrm{O}(190 \mathrm{mg} / \mathrm{L})$, $\mathrm{CuCl}_{2} \cdot 2 \mathrm{H}_{2} \mathrm{O}(2.00 \mathrm{mg} / \mathrm{L}), \mathrm{NiCl}_{2} \cdot 6 \mathrm{H}_{2} \mathrm{O}(24.00 \mathrm{mg} / \mathrm{L})$,

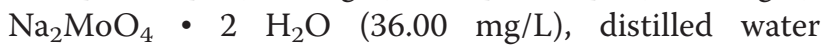
$(990 \mathrm{~mL})$, followed by the addition of $5 \mathrm{~mL}$ of vitamin solution containing vitamin $\mathrm{B}_{12}(50 \mathrm{mg} / \mathrm{L})$, pantothenic acid $(50 \mathrm{mg} / \mathrm{L})$, riboflavin $(50 \mathrm{mg} / \mathrm{L})$, pyridoxamine- $\mathrm{HCl}$ $(10 \mathrm{mg} / \mathrm{L})$, biotin $(20 \mathrm{mg} / \mathrm{L})$, folic acid $(20 \mathrm{mg} / \mathrm{L})$, nicotine amide $(25 \mathrm{mg} / \mathrm{L})$, nicotinic acid $(25 \mathrm{mg} / \mathrm{L}), \alpha$-lipolic acid (50 mg/L), p-aminobenzoic acid (50 mg/L), and thiamine$\mathrm{HCl} \cdot 2 \mathrm{H}_{2} \mathrm{O}(50 \mathrm{mg} / \mathrm{L})$. Both trace element solution and vitamin solution were added using a sterile syringe filter. Medium was excessively degassed with argon, inoculated with preculture, and cyclohexanol $(100 \mu \mathrm{L} / \mathrm{L})$ was added as the carbon source. The culture was shaken reciprocally in air-tight $2 \mathrm{~L}$ bottles for 4 days at $150 \mathrm{rpm}$ at $30^{\circ} \mathrm{C}$. Cells were harvested by centrifugation and purified as previously described (Jin et al. 2011). The cell-free extract of $A$. denitrificans was applied to a DEAE Sepharose column $(28 \mathrm{~mL})$ previously equilibrated with buffer A $(20 \mathrm{mM}$ Tris- $\mathrm{HCl}, \mathrm{pH}$ 7.8). The elution was performed with buffer B (20 mM Tris- $\mathrm{HCl}, 1 \mathrm{M} \mathrm{NaCl}, \mathrm{pH}$ 7.8) with a gradient from $0 \%$ to $50 \%$ at a flow rate of $1 \mathrm{~mL} / \mathrm{min}$.

TADH was produced according to previously described procedures (Höllrigl et al. 2008; Hollmann et al. 2005). E. coli BL21 (DE3) containing pASZ2 (pET 11a derivative containing the gene for TADH) was grown in Overnight Express TM Autoinduction System (Novagene) at $37^{\circ} \mathrm{C}$ for $24 \mathrm{~h}$. Harvested cells were resuspended in buffer, broken using a French press and incubated at $80^{\circ} \mathrm{C}$ for 
20 minutes. After ultracentrifugation the supernatant was used directly without further purification.

\section{Native PAGE and activity staining of MhyADH and TADH}

Native polyacrylamide gel electrophoresis (PAGE) was performed using 4-15\% gradient gels (Phast Gel system form GE Healthcare Life Sciences). Partially purified enzyme preparations solution (concentration of stocks: MhyADH $=1.5 \mathrm{mg} / \mathrm{ml}, \mathrm{TADH}=1.0 \mathrm{mg} / \mathrm{mL}$ ) were applied on gel, and gels were run on an PhastSystem separation and control unit from Pharmacia using the predefined program for native gels at $12^{\circ} \mathrm{C}$. For size determination a standard protein calibration kit (GE Healthcare Life Sciences) containing albumin (66 kDa), lactate dehydrogenase $(140 \mathrm{kDa})$, catalase $(232 \mathrm{kDa})$, ferritin $(440 \mathrm{kDa})$, and thyroglobulin $(669 \mathrm{kDa})$ was used. Activity staining was performed with $30 \mathrm{~mL}$ of $100 \mathrm{mM}$ Tris- $\mathrm{HCl}(\mathrm{pH} 7.8)$ containing $0.6 \mathrm{mM} \mathrm{NAD}^{+}$(for TADH), $60 \mu \mathrm{M}$ methylene blue (for 3-hydroxycyclohexanone dehydrogenase), and $0.3 \mathrm{mM}$ nitro blue tetrazolium chloride. The staining was initiated with the addition of $1 \mathrm{mM} 2$-cyclohexenone or 3hydroxycyclohexanone and was carried out at room temperature. As soon as blue bands were visible, the staining solution was replaced by water and destaining was performed for $1 \mathrm{~h}$. Standard proteins and partly purified enzyme preparations were stained with SimplyBlue ${ }^{\mathrm{Tm}}$ SafeStain (Novex) and destained with distilled water.

\section{Preparative activity tests}

Reactions were carried out in $1.5 \mathrm{~mL}$ screw-capped glass vials to prevent evaporation of substrate/product. Shaking was performed in a heated table top shaker at $30^{\circ} \mathrm{C}$. The reaction was buffered using $100 \mathrm{mM}$ Tris- $\mathrm{HCl}$ buffer at $\mathrm{pH} 7.8$ at a total volume of $1 \mathrm{~mL}$ containing $1.5 \mathrm{mg}$ partially purified MhyADH. Substrate 2-cyclohexenone or xanthine (5 mg, $0.05 \mathrm{mmol}$, final concentration $50 \mathrm{mM}$ ) was added (when xanthine was used, DMSO was used to improve the solubility). For blank reactions the setup was the same without the addition of enzyme. Reactions were allowed to proceed at the given temperature for $3 \mathrm{~h}$ and $24 \mathrm{~h}$. For work-up, the aqueous reaction mixtures were saturated with $\mathrm{NaCl}$ followed by extraction with ethyl acetate $(2 \times 0.5 \mathrm{~mL})$. Combined organic layers were dried over $\mathrm{Na}_{2} \mathrm{SO}_{4}$ and analysed on GC.

The same test was applied for the fractions collected from the purification to track back the hydratase activity. For this activity test blanks were prepared as follows: $0.5 \mathrm{~mL}$ of the collected fraction was denaturated by heat at $99^{\circ} \mathrm{C}$ for $30 \mathrm{~min}$. These samples were cooled down and threatened in the same way as the non denaturated samples. Samples were directly mixed with substrate (2cyclohexenone, $5 \mathrm{mg}, 0.04 \mathrm{mmol}$ ) and shaken at $30^{\circ} \mathrm{C}$ for $3 \mathrm{~h}$. The reactions were stopped by the addition of $\mathrm{NaCl}$ to ensure a saturated solution followed by the extraction with EtOAc (2 times $0.5 \mathrm{~mL}$ ). Combined organic phases were dried with $\mathrm{Na}_{2} \mathrm{SO}_{4}$ and analysed on GC. Dodecane was used as an internal standard.

\section{Synthesis of 3-hydroxycyclohexanone}

Since substrate 2-cyclohexenone is commercially available, only 3-hydroxycyclohexanone needed to be synthesised following a previously described procedure (Karmee et al. 2011). A solution of $\mathrm{K}_{2} \mathrm{Cr}_{2} \mathrm{O}_{7}$ (3.74 g, $12.0 \mathrm{mmol}$ ) in conc. $\mathrm{H}_{2} \mathrm{SO}_{4}(3 \mathrm{~mL})$ and water $(15 \mathrm{~mL})$ was added dropwise to a stirred solution of cyclohexane-1,3-diol (4.34 g, $37.3 \mathrm{mmol})$ in $\mathrm{Et}_{2} \mathrm{O}(15 \mathrm{~mL})$. After the addition, the reaction was allowed to proceed at room temperature for $3 \mathrm{~h}$. Work-up was performed by extraction with $\mathrm{Et}_{2} \mathrm{O}(5 \times 30 \mathrm{~mL})$. Combined organic layers were dried over $\mathrm{Na}_{2} \mathrm{SO}_{4}$ and solvents were evaporated under reduced pressure. Purification was performed using silica gel column chromatography (eluent system: petroleum ether: ethyl acetate $=1: 1$ ). 3-Hydroxycyclohexanone was obtained as a yellowish oil (2.14 g, $18.75 \mathrm{mmol}, 50 \%$ yield). NMR $\left(\mathrm{CDCl}_{3}, 400 \mathrm{MHz}\right): \delta$ $(\mathrm{ppm})=1.64-1.80 \quad(2 \mathrm{H}, \mathrm{m}) ; 1.96-2.11(2 \mathrm{H}, \mathrm{m}) ; 2.29$ $(2 \mathrm{H}, \mathrm{t}, J=6.6 \mathrm{~Hz}) ; 2.39(1 \mathrm{H}, \mathrm{dd}, J=7.5 \mathrm{~Hz}, 14.1 \mathrm{~Hz})$, $2.46(1 \mathrm{H}, \mathrm{s}), 2.63(1 \mathrm{H}, \mathrm{dd}, J=4.1 \mathrm{~Hz}, 14.1 \mathrm{~Hz})$; 4.14-4.21 $(1 \mathrm{H}, \mathrm{m}) .{ }^{13} \mathrm{C} \mathrm{NMR}\left(\mathrm{CDCl}_{3}, 100 \mathrm{MHz}\right): \delta(\mathrm{ppm})=20.5$, 32.4, 40.7, 50.1, 69.3, 210.8. Obtained NMR results were in accordance with literature (Karmee et al. 2011). GC-MS (EI, $70 \mathrm{eV}): m / z=114\left(\mathrm{M}^{+}, 24\right), 73$ (13), 71 (33), 69 (13), 68 (45), 60 (46), 58 (30), 57 (19), 55 (66), 54 (15), 44 (99), 43 (100), 42 (94), 41 (48), 40 (13).

\section{Analytical methods}

The spectrometric activity assay for MhyADH and TADH was carried out at room temperature in a quartz cuvette. The reaction mixture $(0.9 \mathrm{~mL})$ contained $1 \mathrm{mM}$ substrate (either 2-cyclohexenone or 3-hydroxycyclohexanone) and $60 \mu \mathrm{M}$ dichlorophenol indophenol (DCPIP) as the electron acceptor. The reaction system was buffered using a $100 \mathrm{mM}$ Tris- $\mathrm{HCl}$ buffer at $\mathrm{pH}$ 7.8. The reaction was initiated by addition of $0.1 \mathrm{~mL}$ of enzyme solution (concentration of stocks: $\mathrm{MhyADH}=1.5 \mathrm{mg} / \mathrm{ml}$, $\mathrm{TADH}=1.0 \mathrm{mg} / \mathrm{mL}$ ). The spectrum of the reaction mixture were recorded on a Hewlett-Packard 8452A diode array spectrophotometer at an interval of $60 \mathrm{~s}$ and absorbance change at $578 \mathrm{~nm}$ (DCPIP, $\varepsilon=16.8 \mathrm{~cm}^{-1} \mathrm{mmol}^{-1}$ ) was followed.

Conversion of 2-cyclohexenone to 3-hydroxycyclohexanone was determined by GC (column: CP-Wax $52 \mathrm{CB}$ [Varian] $50 \mathrm{~m} \times 0.53 \mathrm{~mm} \times 2.0 \mu \mathrm{m})$ using an internal standard (dodecane) and calibration lines for both substrate (2-cyclohexenone) and product (3-hydroxycyclohexanone) with the following specifications and temperature program: Start $80^{\circ} \mathrm{C}$, hold for $5 \mathrm{~min}$, with a rate of $50^{\circ} \mathrm{C} /$ min to $140^{\circ} \mathrm{C}$, hold for $3 \mathrm{~min}$, with a rate of $50^{\circ} \mathrm{C} / \mathrm{min}$ to $200^{\circ} \mathrm{C}$, hold for $3 \mathrm{~min}$, with a rate of $50^{\circ} \mathrm{C} / \mathrm{min}$ to $250^{\circ} \mathrm{C}$, 
hold for $1 \mathrm{~min}$; injector temperature: $250^{\circ} \mathrm{C}$, detector temperature: $270^{\circ} \mathrm{C}$, total nitrogen flow: $20 \mathrm{~mL} / \mathrm{min}$; Retention times: 2-cyclohexenone: $7.22 \mathrm{~min}$, 3-hydroxycyclohexanone: $12.90 \mathrm{~min}$, dodecane: $3.89 \mathrm{~min}$. GC-MS analysis was carried out using $\mathrm{He}$ as carrier gas and a Varian FactorFour VF-1 ms column $(25 \mathrm{~m} \times 0.25 \mathrm{~mm} \times 0.4 \mu \mathrm{m})$, with detection by electron impact (EI) ionisation at $70 \mathrm{eV}$ and quadrupole mass selection.

${ }^{1} \mathrm{H}$ - and ${ }^{13} \mathrm{C}$ NMR spectra were recorded on a $400 \mathrm{MHz}$ spectrometer $\left({ }^{1} \mathrm{H}: 400 \mathrm{MHz},{ }^{13} \mathrm{C}: 100 \mathrm{MHz}\right)$ and chemical shifts $(\delta)$ are given in ppm. Column chromatography was performed using silica gel 60 (particle size 0.063-0.2 mm). Ethyl acetate and petroleum ether used for column chromatography were distilled before use. For TLC silica gel Plates $60 \mathrm{~F}_{254}$ were used.

\section{Results}

Staining of 3-hydroxycyclohexanone dehydrogenase activity in native gel

The results from previous experiments indicated that MhyADH is a bi-functional enzyme that possesses next to its hydratase activity also a dehydrogenase activity. This conclusion was based on the fact that the native gel staining gave positive results when either 2-cyclohexenone or 3-hydroxycyclohexanone were used in the experiment. Having gained more insight into the nonenzymatic water addition reaction, a more detailed study is necessary now. Since the hydration reaction of 2cyclohexenone is a base-catalysed reaction and can take place spontaneously or catalysed by amino acids (Resch et al. 2013) the staining experiment was repeated. Using an alcohol dehydrogenase (TADH, the thermostable alcohol dehydrogenase from Thermus sp. ATN1), which is known to convert cyclic substrates like 3-hydroxycyclohexanone, as a control. At the same time this enzyme is not described to have a hydratase activity and is therefore suited to probe the reliability of the assay. TADH has a homotetrameric structure with a molecular weight of around $149 \mathrm{kDa}$ (Höllrigl et al. 2008) MhyADH was described as a heterotrimeric enzyme comprised of three subunits with an approximate molecular weight of 20, 30, and $90 \mathrm{kDa}$, respectively (Jin et al. 2011).

The native activity staining was started using 2cyclohexenone or 3-hydroxycyclohexanone as substrates to stain the MhyADH and the TADH band. In the case of 3-hydroxycyclohexanone as a substrate both bands are expected to be stained. Indeed, this is the case. Starting from 2-cyclohexenone only the MhyADH band should be stained due to its bi-functionality. If, however, the recently revealed chemical base-catalysed reaction takes place, both bands should be stained. Contrary to our initial assumption, this is the case and both TADH and MhyADH are stained and a false positive result is observed. In all cases - no matter whether 2-cyclohexenone or 3-hydroxycyclohexanone were used as substrates, both the bands for MhyADH and TADH were stained, indicating that the chemical water addition background reaction is fast enough to provide sufficient amounts of 3-hydroxycyclohexanone to serve as a substrate for the conversion to 1,3-cyclohexanedione and which resulted in false positive results for hydratase activity (Figure 2).

\section{Spectrophotometric assay}

The results gained from the native PAGE staining were also reproduced in the colourimetric assay that was previously employed to test the substrate acceptance of the proposed hydratase (Dangel et al. 1989; Jin et al. 2010; Jin et al. 2011). TADH was again used as a reference enzyme. The reaction was spectrometrically followed over time detecting the decrease of absorbance caused by a colour change from blue to colourless in the course of DCPIP reduction (See Figure 3).

As shown in Table 1 and in Additional file 1 a significant decrease in absorbance is measured when MhyDH is incubated with either 2-cyclohexenone or 3-hydroxycyclohexanone (entry 6 and 7). However, also when TADH is incubated with 2-cyclohexenone, a fast decrease in the absorbance is detectable (entry 8). This experiment confirms the results of the gel staining, indicating that 3-hydroxycyclohexanone is formed spontaneously and is then further converted to 1,3-cyclohexanedione by the dehydrogenase activity. To ensure that there is no influence on the absorbance caused by the substrates

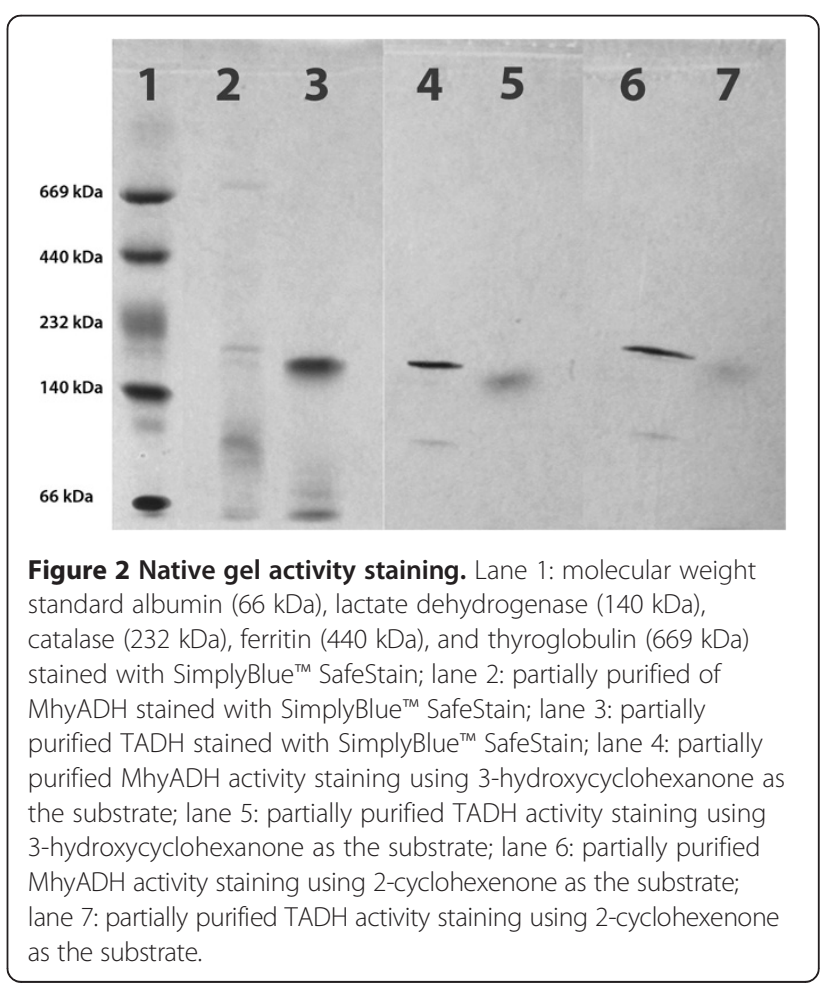




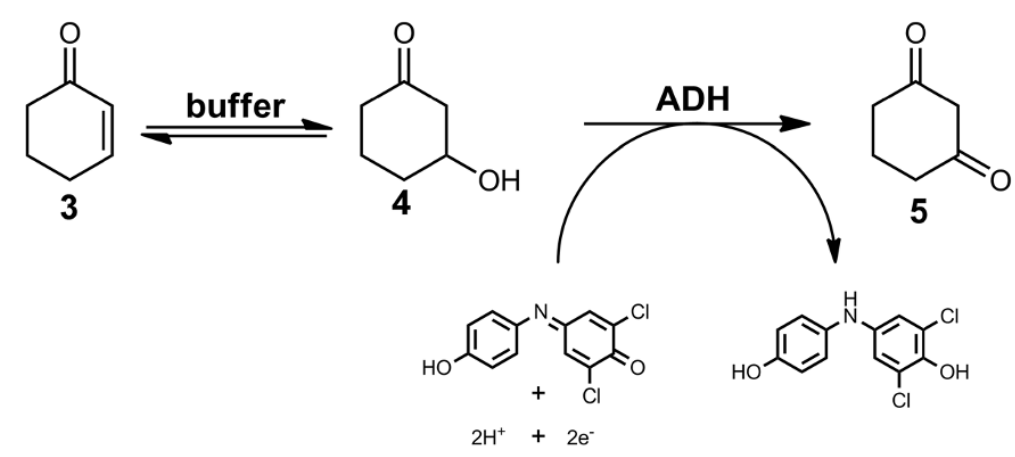

blue

colourless

Figure $\mathbf{3}$ Principle of the spectrophotometric assay. The water addition to $\mathbf{3}$ is taking place spontaneously and the formed $\mathbf{4}$ is further converted by the ADH activity. The oxidised state of DCPIP is blue, the reduced colourless. DCPIP serves as an electron acceptor for the ADH, and its reduction can be detected as a decrease of absorbance. Results from the spectrophotometric assay using DCPIP are given in Table 1.

or the enzyme preparations, control reactions of all possible combinations with DCPIP were performed and no decrease in absorbance was observed (entries 1-5).

\section{Activity tests for hydratase activity}

In addition to the native gel activity staining we also conducted preparative tests using partly purified enzyme solution and no addition of electron acceptors to stop the reaction at the Michael addition product. If hydratase activity is present, this should lead to the formation of 3-hydroxycyclohexanone and no oxidation to 1,3cyclohexanedione should take place. The detailed characterisation of the water addition reaction catalysed by amino acids also showed that the reaction is subject to an equilibrium that lies on the 2-cyclohexenone side rather than on the 3-hydroxycyclohexanone side. This leads to a maximal possible conversion of around $25 \%$. (Stiles and Longroy 1961; Resch et al. 2013). Taking this into account, utilising an authentic product references, and the proper analytical system to follow the conversion, tests with partly purified MhyADH solution were performed. These experiments revealed that no water

Table 1 Results of the spectrophotometric assay

\begin{tabular}{lll}
\hline Entry & Experiment & $\boldsymbol{\Delta} \mathbf{A b s} / \mathbf{m i n}^{[\mathbf{a}]}$ \\
\hline 1 & DCPIP + buffer & 0.0003 \\
2 & DCPIP $+\mathbf{3}$ & -0.0008 \\
3 & DCPIP $+\mathbf{4}$ & -0.0012 \\
4 & DCPIP + TADH & -0.0001 \\
5 & DCPIP + MhyADH & -0.0007 \\
6 & DCPIP $+\mathbf{3}+\mathrm{MhyADH}$ & -0.0087 \\
7 & DCPIP $+\mathbf{4}+\mathrm{MhyADH}$ & -0.0080 \\
8 & DCPIP $+\mathbf{3}+\mathrm{TADH}$ & -0.0199 \\
\hline
\end{tabular}

[a] Decrease of absorbance is given as $\Delta$ absorbance unit per min. 3: 2cyclohexenone, 4: 3-hydroxycyclohexanone. The graph to the data shown in the table can be found in the Additional file 1. addition faster than the background caused by basic condition of the buffer took place, indicating that the hydratase activity is either not stable under these conditions and hence deactivated, or not present.

\section{Discussion}

The degradation pathway of cyclohexanol in A. denitrificans describes an array of enzymes capable of dealing with the detoxification of this substance. This pathway includes a hydratase and an alcohol dehydrogenase catalysing the addition of water and the subsequent oxidation of the formed alcohol by an alcohol dehydrogenase (Dangel et al. 1988, 1989). Attempts to identify and make use of the hydratase described were done previously and the enzyme was identified with a bi-functional nature having both a hydratase and an alcohol dehydrogenase activity (Jin et al. $2010,2011)$. The addition of water to $\alpha, \beta$-unsaturated ketones is known as the Michael addition (Tokoroyama 2010), where water serves as the nucleophile and therefore as the Michael donor. Ongoing research on the Michael addition of water using 2-cyclohexenone showed that this reaction is in general base catalysed and that also simple amino acids serve as catalysts using 2-cyclohexenone and structurally related compounds as substrates (Resch et al. 2013). Based on this new insights, the results and the methodology used in previous studies to identify the hydratase from $A$. denitrificans as a bi-functional enzyme need to be reinterpreted.

With a more detailed understanding of the Michael addition of water to 2-cyclohexenone we also obtained more insight into the reliability of the activity assay used to find the hydratase. Knowing that the water addition can take place in a spontaneous manner, the significance of the spectrophotometric assay needs to be doubted. Several conclusions from the control experiments using $\mathrm{TADH}$ as a comparative enzyme - where no hydratase activity is described - can be drawn. 
(a) MhyADH is not a bi-functional enzyme but a structurally demanding $\mathrm{ADH}$; (b) MhyADH is a bi-functional enzyme but the hydratase activity is not stable when isolated; (c) Using the coupled assay with 2-cyclohexenone as a substrate does not give reliable hints for the presence of a hydratase; (d) Using native gel staining (based on the same principle) does not give reliable hints for the presence of a hydratase.

All these conclusions can now be applied to the proposed degradation pathway of cyclohexanol (Dangel et al. 1989) as well. It is not clear if a hydratase needs to be present for the water addition step. The water addition might also occur spontaneously and even though the dehydrogenase that catalyses the formation of 1,3-cyclohexanedione might be enantioselective, due to the equilibrium and the resulting dynamic kinetic resolution via the prochiral 2-cyclohexenone the preferred enantiomer of 3-hydroxycyclohexanone is always present.

The biochemical characterisation of MhyADH performed previously, revealed that the enzyme is a heterotrimere comprised of three subunits of different size and each one harbouring a different co-factor. The large subunit contains a molybdopterin, the medium subunit a FAD and the small subunit a [2Fe-2S] cluster (Jin and Hanefeld 2011). This particular enzyme architecture is also found in the molybdenum-containing hydroxylase family. Other members of this family are for example xanthine dehydrogenase (Dietzel et al. 2009; Hille 1996), quinoline 2-oxidoreductase (Bonin et al. 2004; Hille 1996), and nicotinic acid dehydrogenase (Schräder et al. 2002; Hille 1996). Enzymes from the xanthine oxidase family are capable of introducing a hydroxyl group to the substrate where water is used as a source of the oxygen atom (Howes et al. 1996; Leimkühler et al. 2004; Okamoto et al. 2004; Bonam and Ludden 1987). All these enzymes share a common structural feature; they are composed of three subunits of different size whereby each subunit holds a different cofactor. In order to learn more about the function of MhyADH and due to its close relation to xanthine dehydrogenase, MhyADH was also tested for its ability to convert xanthine. In these tests no activity towards this substrate was found. Looking on the structural complexity of MhyADH, the question on the function of the different subunits arises. Xanthin dehydrogenase, quinoline 2-oxidoreductase or nicotinic acid dehydrogenase all belong to the family of molybdenum-containing oxidoreductases and the reaction these enzymes are catalysing are - compared to their complex quaternary structure - all quite simple. The ADH involved in the degradation of cyclohexanol by $A$. denitrificans can therefore be assigned to the group of molybdenum-containing oxidoreductases being able to catalyse the oxidation of cyclic alcohols and therefore displaying a completely different substrate pattern than for example xanthine dehydrogenase.
The additional experiments performed show the importance of detailed knowledge of a reaction system. The Michael addition of water is a rarely investigated reaction and detailed characterization is hardly found in literature. To ensure its presents, additional investigations on the possible hydratase in $A$. denitrificans are necessary including variation of the growth conditions and a screening methodology different from the coupled spectrophotometric assay needs to be employed to minimize the risk of producing false positive results.

\section{Additional file}

\section{Additional file 1: A: Principle of the colorimetric assay. The \\ water addition is taking place spontaneously and the formed \\ 2-cyclohexenone is further converted by the ADH activity. The oxidised state of DCPIP is blue, the reduced colourless. DCPIP serves as a redox donor for the ADH. In parallel DCPIP is reduced which can be detected as a decrease of absorption. B: Results from the colorimetric assay using DCPIP. All control reactions are represented as empty marks. Reactions containing either TADH or MhyADH are represented as filled marks. 1: 2-cyclohexenone, 2: 3-hydroxycyclohexanone.}

\section{Competing interests}

The authors declare that they have no competing interests.

\section{Acknowledgements}

Financial support is provided by the Austrian Science Fund (FWF) for V. Resch in terms of an "Erwin-Schroedinger" Fellowship (J3292). A senior research fellowship of China Scholarship Council-Delft University of Technology Joint Program to B.-S. Chen is gratefully acknowledged. Furthermore S. Gargiulo and F. Hollmann are cordially thanked for providing enzyme preparations of TADH.

Received: 19 November 2013 Accepted: 8 January 2014

Received: 19 November 2013 Accepted: 8

\section{References}

Boersma AJ, Coquière D, Geerdink D, Rosati F, Feringa BL, Roelfes G (2010a) Catalytic enantioselective syn hydration of enones in water using a DNA-based catalyst. Nat Chem 2:991-995

Boersma AJ, Megens RP, Feringa BL, Roelfes G (2010b) DNA-based asymmetric catalysis. Chem Soc Rev 39:2083-2092

Bonam D, Ludden PW (1987) Purification and characterization of carbon monoxide dehydrogenase, a nickel, zinc, iron-sulfur protein, from Rhodospirillum rubrum. J Biol Chem 262:2980-2987

Bonin I, Martins BM, Purvanov V, Fetzner S, Huber R, Dobbek H (2004) Active site geometry and substrate recognition of the molybdenum hydroxylase Quinoline 2-Oxidoreductase. Structure 12:1425-1435

Dangel W, Tschech A, Fuchs G (1988) Anaerobic metabolism of cyclohexanol by denitrifying bacteria. Arch Microbiol 150:358-362

Dangel W, Tschech A, Fuchs G (1989) Enzyme reactions involved in anaerobic cyclohexanol metabolism by a denitrifying Pseudomonas species. Arch Microbiol 152:273-279

Dietzel U, Kuper J, Doebbler JA, Schulte A, Truglio JJ, Leimkühler S, Kisker C (2009) Mechanism of substrate and inhibitor binding of rhodobacter capsulatus xanthine dehydrogenase. J Biol Chem 284:8768-8776

Hille R (1996) The mononuclear molybdenum enzymes. Chem Rev 96:2757-2816

Holland H, Gu J-X (1998) Preparation of (R)-3-hydroxy-3-alkylbutanolides by biocatalytic hydration of 3-alkyl-2-butenolides using Rhodococcus rhodochrous. Biotechnol Lett 20:1125-1126

Hollmann F, Kleeb A, Otto K, Schmid A (2005) Coupled chemoenzymatic transfer hydrogenation catalysis for enantioselective reduction and oxidation reactions. Tetrahedron: Asymmetry 16:3512-3519

Höllrigl V, Hollmann F, Kleeb A, Buehler K, Schmid A (2008) TADH, the thermostable alcohol dehydrogenase from Thermus sp. ATN1: a versatile new biocatalyst for organic synthesis. Appl Microbiol Biotechnol 81:263-273 
Howes BD, Bray RC, Richards RL, Turner NA, Bennett B, Lowe DJ (1996) Evidence favoring molybdenum-carbon bond formation in xanthine oxidase action: 170- and 13C-ENDOR and kinetic studies. Biochemistry 35:1432-1443

Jin J, Hanefeld U (2011) The selective addition of water to C = C bonds; enzymes are the best chemists. Chem Commun 47:2502-2510

Jin J, Oskam PC, Karmee SK, Straathof AJJ, Hanefeld U (2010) MhyADH catalysed Michael addition of water and in situ oxidation. Chem Commun 46:8588-8590

Jin J, Straathof AJ, Pinkse MH, Hanefeld U (2011) Purification, characterization, and cloning of a bifunctional molybdoenzyme with hydratase and alcohol dehydrogenase activity. Appl Microbiol Biotechnol 89:1831-1840

Karmee SK, van Oosten R, Hanefeld U (2011) Kinetic resolution of 3-hydroxycyclohexanone using different lipases. Tetrahedron: Asymmetry 22:1736-1739

Leimkühler S, Stocker AL, Igarashi K, Nishino T, Hille R (2004) The role of active site glutamate residues in catalysis of Rhodobacter capsulotus xanthine dehydrogenase. J Biol Chem 279:40437-40444

Mahajan SS, Sharma MM, Sridhar T (2006) Hydration of 2-Cyclohexen-1-one to 3-Hydroxycyclohexanone Using Solid Acid Catalysts. Ind Eng Chem Res 45:5246-5250

Mechichi T, Stackebrandt E, Fuchs G (2003) Alicycliphilus denitrificans gen. nov., sp. nov., a cyclohexanol-degrading, nitrate-reducing $\beta$-proteobacterium. Int J Syst Evol Microbiol 53:147-152

Okamoto K, Matsumoto K, Hille R, Eger BT, Pai EF, Nishino T (2004) The crystal structure of xanthine oxidoreductase during catalysis: implications for reaction mechanism and enzyme inhibition. Proc Natl Acad Sci USA 101:7931-7936

Oosterkamp MJ, Veuskens T, Talarico Saia F, Weelink SA, Goodwin LA Daligault HE, Bruce DC, Detter JC, Tapia R, Han CS, Land ML, Hauser LI, Langenhoff AA, Gerritse J, van Berkel WJ, Pieper DH, Junca H, Smidt H, Schraa G, Davids M, Schaap PJ, Plugge CM, Stams AJ (2013) Genome analysis and physiological comparison of Alicycliphilus denitrificans strains BC and K601(T.). PLoS One 6:e66971

Oosterkamp MJ, Veuskens T, Plugge CM, Langenhoff AA, Gerritse J, van Berkel WJ, Pieper DH, Junca H, Goodwin LA, Daligault HE, Bruce DC, Detter JC, Tapia R, Han CS, Land ML, Hauser LJ, Smidt H, Stams AJ (2011) Genome sequences of Alicycliphilus denitrificans strains BC and K601T. J Bacteriol 18:5028-5029

Resch V, Seidler C, Chen B-S, Degeling I, Hanefeld U (2013) On the Michael Addition of Water to $\alpha, \beta$-Unsaturated Ketones Using Amino Acids. Eur J Org Chem 2013:7697-7704

Riedel K, Krekeler H (1972) Verfahren zur Herstellung von 3-Hydroxycyclohexanon. DE, Germany, p 2205225

Schräder T, Thiemer B, Andreesen J (2002) A molybdenum-containing dehydrogenase catalyzing an unusual 2-hydroxylation of nicotinic acid. Appl Microbiol Biotechnol 58:612-617

Stiles M, Longroy A (1961) Kinetics of the acid-catalyzed interconversion of 3-hydroxycyclohexanone and 2-cyclohexenone: reinterpretation of the decomposition of 3-alkoxyallylic alcohols. Tetrahedron Lett 2:337-340

Tokoroyama T (2010) Discovery of the Michael Reaction. European Journal of Organic Chemistry 2010:2009-2016

Wang X, Sui D, Huang M, Jiang Y (2006) Highly effective hydration of olefins using a wool-palladium complex as a catalyst. Polym Adv Technol 17:163-167

Weelink SA, Tan NC, ten Broeke H, van den Kieboom C, van Doesburg W, Langenhoff AA, Gerritse J, Junca H, Stams AJ (2008) Isolation and characterization of Alicycliphilus denitrificans strain $\mathrm{BC}$, which grows on benzene with chlorate as the electron acceptor. Appl Environ Microbiol 21:6672-6681

doi:10.1186/s13568-014-0030-2

Cite this article as: Resch et al:: Michael hydratase alcohol

dehydrogenase or just alcohol dehydrogenase? AMB Express 2014 4:30. 